\title{
Scanning Electron Microscopy of Ferrisia Malvastra (Mcdaniel) (Hemiptera: Pseudococcidae)
}

\author{
Hedaya H. Karam ${ }^{1}$, M. A. H. Alziber ${ }^{2}$, A. M. El-Minshawy ${ }^{1}$, Hanan M. Ramadan ${ }^{1}$ \\ ${ }^{1}$ Department of Applied Entomology and Zoology, Faculty of Agriculture, Alexandria University \\ ${ }^{2}$ Dept. of Plant Protection, Faculty of Agriculture Studies, Sudan University of Science and Technology
}

\begin{abstract}
In the present study Ferrisia malvastra (McDaniel) is recorded for the first time in Sudan, since only four species were recorded there, i.e. Planococcus citri (Risso), Ferrisia virgata (Cockerell), Maconellicoccus hirsutus (Green) and Phenacoccus solenopsis Tinsley. The present study deals with the morphology of the female of this mealybug by using electron microscope. The ultrastructure of antennae, claw and its digitules, anal opening, valva, cerarius, circulus and wax producing pores were examined and illustrated. The result revealed that antennae consists of 8 segments, they were measured and their sensella were described. The claw denticle is absent and its digitules are knobbed. The circulus is present. There is only one pair of stout conical setae cerarii on the anal lobe, all of these features are used to distinguish between genera of Pseudococcidae. Also, the wax producing pores were illustrated; they are two types, the trilocular pores which produce the fine coiled wax filaments covering the body and forming the lateral wax filaments and the multilocular pores which surrounding the valva and produce the ribbon like wax which form ovisac.
\end{abstract}

Kewwords: SEM study, Ferrisia malvastra.

\section{INTRODUCTION}

The scanning Electron Microscope (SEM) is extremely useful for studying the details of structures on insect cuticle (Zhang et al., 2012). It is expensive and requires special preparation of the material but provides excellent results (Ubero-Pascal et al. 2010).

In mealybugs, the thin and flexible cuticle cause some difficulties in studying the wax-producing pores and ducts. Several studies were carried out on different species of mealybug ultrastructure (Cox and Pearce, 1983a,b; Tewari et al., 1994; Kumar et al., 1997; Vahedi and Mahfar, 2010; Zhang et al., 2012; Beshr, 2015; Sirisena et al., 2015 ; and Khalifa et al., 2019). Morphology of these dermal wax pores and ducts showed variation among variable species.

Ferrisia malvastra (McDaniel) is a newly recorded mealybug in Sudan, in addition to the four species namely, Planococcus citri (Risso), Ferrisia virgata (Cockerell), Phenacoccus hirsutus Green (Schumutterer,1969) and Phenacoccus solenopsis Tinsley (Mohamed 2015) .

The present work was carried out to understand the ultrastructure of some taxonomical characters of F. malvastra.

\section{MATERIALS AND METHODS}

As a matter of fact, the females of mealybugs are used in the morphological studies, therefore, females were collected from citrus seedling and guava trees in

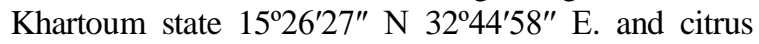
seedling in Kassala state $15^{\circ} 29^{\prime} 09^{\prime \prime}$ N, 36 $25^{\prime} 03^{\prime \prime}$ E. Adult females were killed and preserved in $70 \%$ ethyl alcohol, transferred to the laboratory of Department of Applied Entomology and Zoology, Faculty of Agriculture, Alexandria University, Egypt. Specimens were identified by the first author and kindly confirmed by Dr. Bora Kaydan, Cukurova University, Inamoglu Vactional School, Adana, Turkye. The genus was identified by using the keys of Ferris, (1950); Ezzat, (1962) and Mc Kenzie, (1967) and the species by the key of Kaydan and Gullan (2012).

For SEM preparation, wax was dissolved in $10 \%$ Xylene, then dehydrated by soaking in a series of ethanol (80, $85 \& 90 \%)$ half an hour for each concentration. They were finally dried for two hours at room temperature. The next procedures were carried out at the SEM unit of Faculty of Science, Alexandria University, the dehydrated specimens were glued on a SEM stub using double face sticky tape, some individuals on the dorsal and others on ventral side of body. Specimens were placed in sputter chamber scanning electron (JOELFC-1100E) to coat the specimens with a very thin layer of gold. A computer controlled SEM (JEOL model JSMIT200) was used to scan the specimens from different angles to choose the best micrographs.

\section{RESULTS AND DISCSSION}

\section{Female characteristics of mealybugs Ferrisia} malvastra (McDaniel) using SEM:

Antenna (Fig., 1A) eight segmented, the apical segment is the longest $(11.5 \mu \mathrm{m})$ followed by the fifth $(6$ $\mu \mathrm{m})$, third and fourth segments are equal $(5 \mu \mathrm{m})$, six and seven are equal $(4.5 \mu \mathrm{m})$. Scape wider than long 


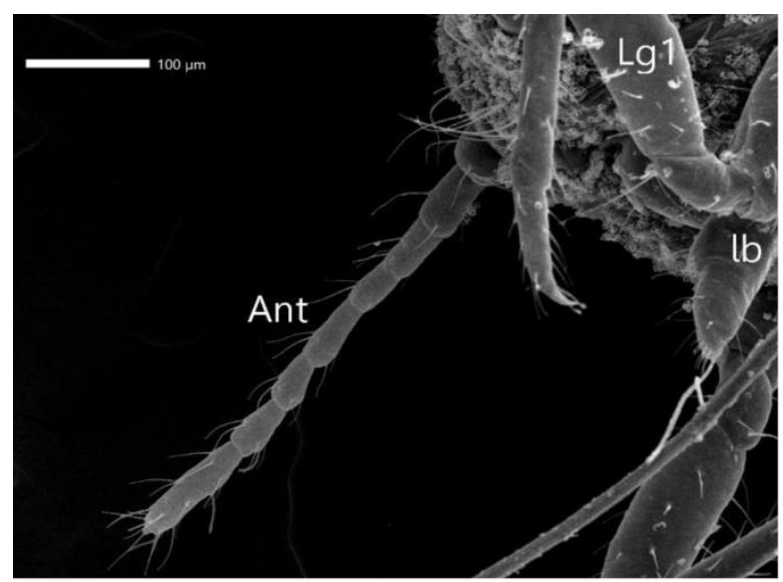

A

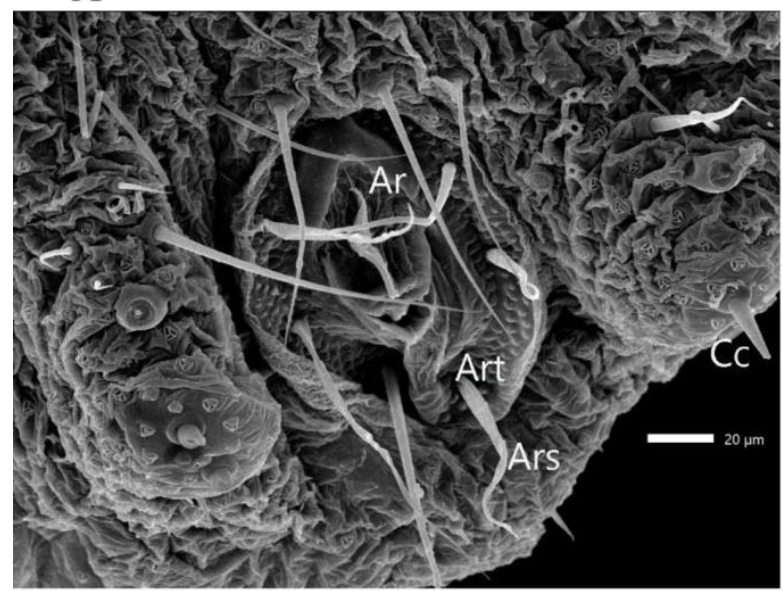

$\mathrm{C}$

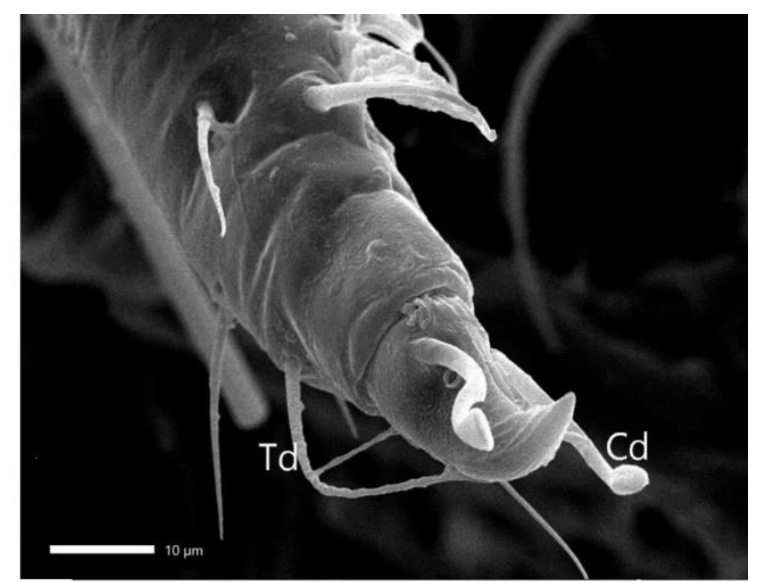

B

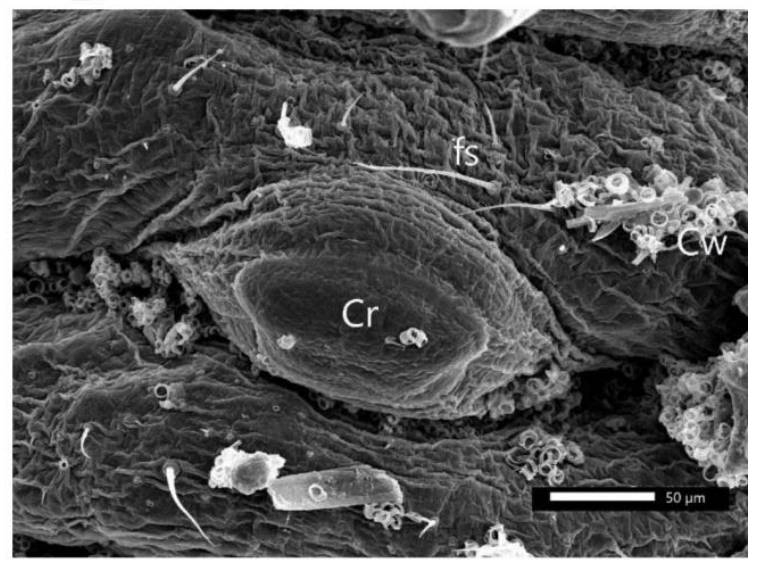

D

Figure 1: Scanning electron micrographs of Ferrisia malvastra showing

A: The eight segmented antenna (Ant.) with sensory setae on each segment, first leg (Lg1) and the segmented labium (lb) with apical trichoid setae.

B: The one segmented tarsus and claw with knobbed claw digitules (Cd) and tarsal digitules (Td).

C: Anal ring (Ar) with row of tubercles (Art) and three pairs of anal ring setae (Ars).

D: Circulus $(\mathrm{Cr})$ on the intersegmental line between fourth and fifth abdominal segment (ventral), fine flagellate setae (fs) and fine coiled wax filaments extruding from trilocular pores $(\mathrm{Cw})$.

(3.7 $\mu \mathrm{m})$, pedicel measured $6 \mu \mathrm{m}$. Each segment from one to seven bears $3-4$ setae. The two preapical antennal segment each has one additional fleshy setae. The apical segment has 5 fleshy thin walled sensellae, 7 trichoid setae arise from basal socket and 1 stiff terminal chaetica, the latter can be easily distinguished from other sensilla by being set on a collar like socket or bulb at the base. Number of antennal segments is a significant taxonomic characters distinguish between genera (Ferris, 1950; Ezzat, 1962 and Mc Kenzie, 1967). Williams and Granara de Willink (1992) mentioned that adult females of Pseudococcidae have four hygroreceptors on the antennae, one on the pedicel, one on segment IV and two on terminal segment. In fact, these sinsella were not observed in the present study.

Labium (Fig., 1A): consists of three segments with four fleshy setae on each side of the terminal segment, in addition to a very fine peg like chaetica sensillae at its tip. As studied in most Sternorrhynchae (the suborder of mealybugs), the apex of antennae and the tip of labium are responsible on the high specificity in feeding (Chapman, 1982). Le Ru et al. (1995) reported 10 pairs of trichoid hairs distributed over the labium of Phenacoccus manihoti Matile-Ferrero and 5 pairs of sensillae chaetica 
(pegs) on its tip. They suggested that these pegs could be involved in the identification of the physical characters of the plant surface before probing the stylets. Also, Alliaume et al. (2018) reported fourteen pairs of different types of sensilla cover the exposed surface of P. aceris Geoffroy of labium.

Claw (Fig. 1B): leg of female mealybug has only one tarsal segment with a single claw, its base usually bears a pair of digitules. In the insect under study as all Ferrisia species the small tooth or denticle on the inner surface of claw is absent. The claw digitules $(\mathrm{Cd})$ are longer than claw and knobbed at apex while the tarsal digitules (Td) are thinner and longer with very fine knob at apex.

Anal ring (Fig. 1C): as in all members of Pseudococcidae the anal opening is situated on the tenth abdominal segment. It is usually surrounded by a sclerotizing ring (Ar) that normally bears six long and slender setae (Ars). In this sclerotized ring numerous irregular pores were found as indicated by many coccidologistes. In our opinion, there are small tubercles arranged in the outer row (Art) as shown in Figure 1C.

Circulus (Fig. 1D): is situated on the ventral side between fourth and fifth abdominal segments. It is large oval -shaped membranous structure $(\mathrm{Cr})$ with lateral extensions. It is free of any hairs or pores. Gullan and Kosztarab, (1997) reported that the circulus acts as an adhesive organ in the mature female to the substrate.

Valva (V) (Fig. 2A): is the female genital opening, its presence indicates the full maturity of female. It is situated in the ventral side on the posterior margin of the eighth abdominal segment. It is a transverse shrinking membranous aperture surrounding by clusters of multilocular pores (mp).

Cerarii (Figs., 1C \&2B): in pseudococcid mealybugs, there are pairs of dorsal cerarii on the body margins. Number of cerarrii (Cc) distinguish between different genera. In Ferrisia spp. only one pair is found on the anal lobe. This anal cerarius consists of two large conical setae with associated numerous trilocular pore in addition to an anal long filament setae (Als).Cox and Pearce, 1983 a \& b) proposed that the cerarii support the waxy filament which produced by the trilocular pores.
Wax pores: are different and taxonomically useful to separate the genera and species. Two types of wax pores were found in the studies species as follows:

Multilocular disc pores (mp) are usually present on the ventral side, especially around the valve (Fig. 2C). Each pore consists of a circle of opening (loculi). Presence of multilocular pores and their distribution on the abdominal segments are diagnostic features distinguishing between Ferrisia spp. In the subject studied mealybugs $F$. mulvastra they are absent on sixth abdominal segments and present anterior and posterior to valve, while in some other species they present only posterior to valva . Figure ( $2 \mathrm{C}$ ) shows the flattened ribbon wax strips (Rw) emerging from a multilocular disc pore. The ribbon-like wax secretion with longitudinal grooves indicated that secretion from a row of pores fused together to form this ribbon.

Kumar et al., (1997) reported that the wax produced by multilocular pores surrounding the valva cover the eggs when laid through genital opening and forming the ovisac.

Trilocular pores: are abundant on the dorsum and venter of body. Each consists of a triangular depression with three elongate narrow opening (loculi) (Fig., 2D).

In mealybugs, waxs produced by different dermal pores to protect the insect from invasion of the body by bacteria, fungi or parasites (Cox and Pearce, 1983b \& Foldi and Pearce, 1985). Zhang et al. (2012) reported that the wax secretion glands consists of three cells, each cell has a large reservoir to store the wax secretion then excreted it through canals.

Hairs covering the body differ in the dorsal side from the ventral side. The ventral hairs are long and flagellate (Fig, 2A) while the dorsal ones are shorter and some of them are lanceolate (dls) (Fig. 2E).

The studied characters in the present work are diagnostic and used by coccidologists to distinguish between genera and even species such as, number of antennal segments, presence or absence of denticle or tooth on the plantar surface of the claw, the presence or absence of circulus and types and position of wax pores. 


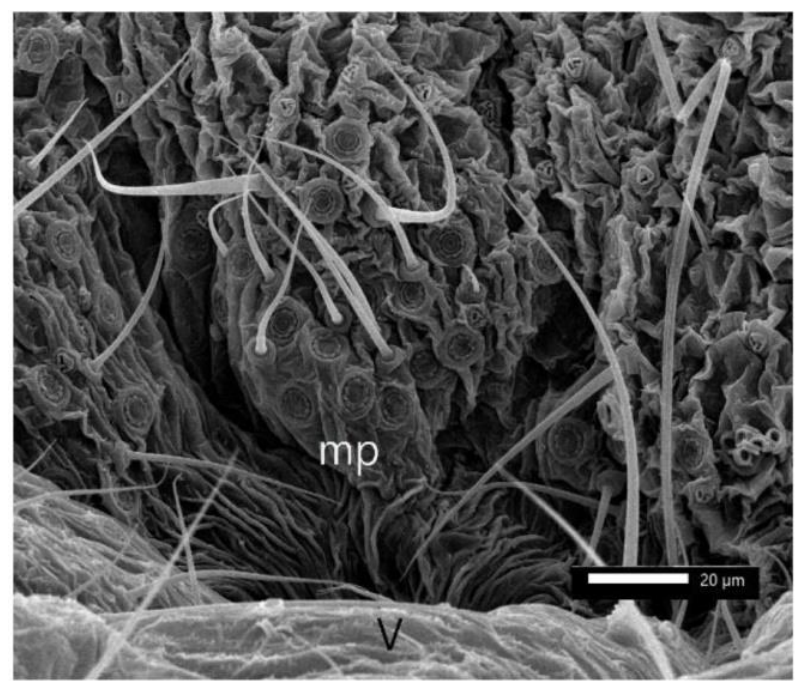

A

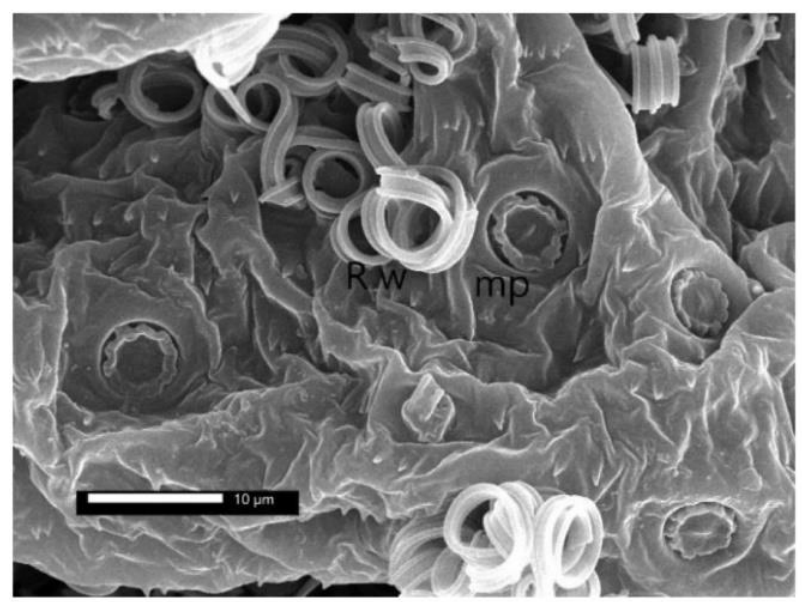

C

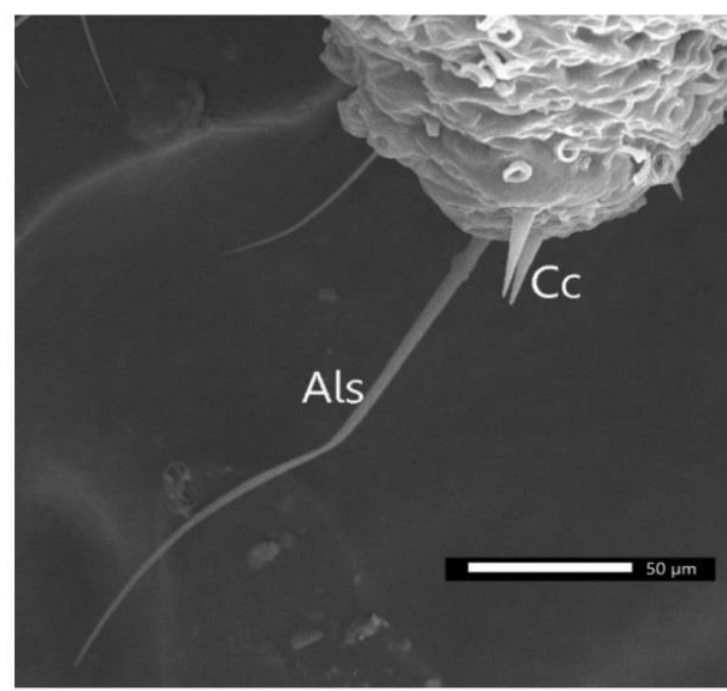

B

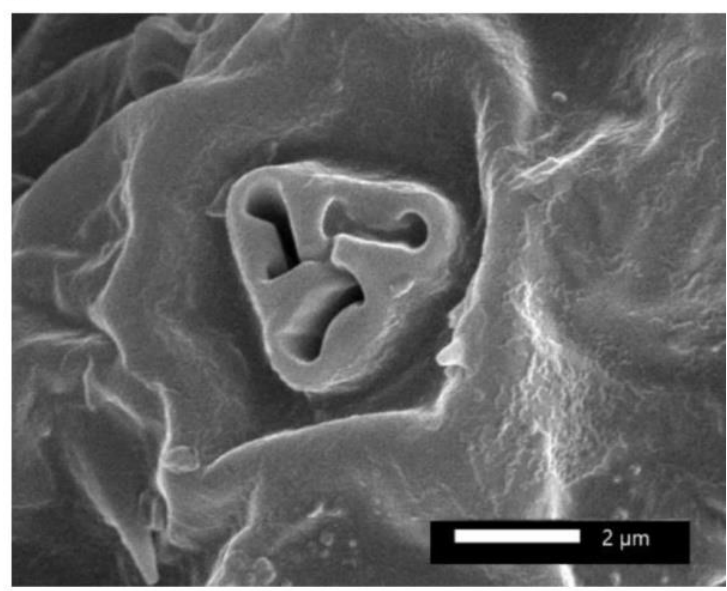

D

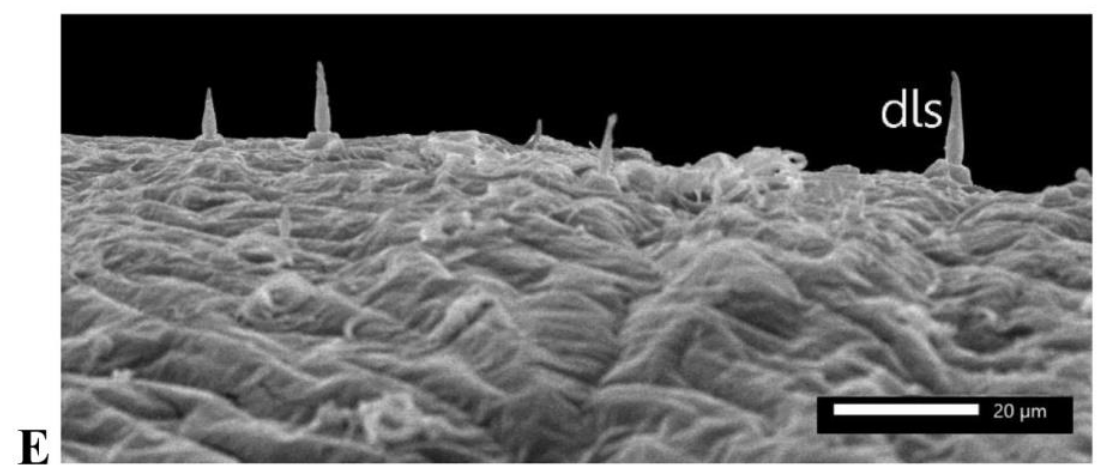

Figure 2: Scanning electron micrographs of Ferrisia malvastra showing

A: Valva $(\mathrm{V})$ surrounding by clusters of multiloclar pores $(\mathrm{mp})$ and long flagellate setae.

B: Anal cerarius $(\mathrm{Cc})$. C: highly magnified multilocular pore (mp) with extruding ribbon like wax secretion (Rw). D: highly magnified trilocular pore E:.Dorsal thick lanceolate setae (dls). 


\section{REFERNCES}

Alliaume, A.; Reinbold, C.; Uzest, M.; Lemaire, O. and Herrbach,E. (2018). Mouthparts morphology of the mealybug Phenacoccus aceris. Bull. Insectology, 71(1), 1 -9.

Beshr, Sahar, H. (2015). Scanning electron microscopy of Icerya aegyptiaca (Douglas, 1890) (Hemiptera: Monophilebidae). J. Alex. Scince Exchange 36 (4), 365 - 372.

Chapman, R. F. (1982). Chemoreception : the significance of receptor numbers. Advances in insect physiology 16, $24-356$.

Cox, J. M. and Pearce, M. J. (1983a). An experimental study of morphological variation in mealybugs (Homoptera: Coccoidea: Pseudococcidae). Yst. Entomol. 8, 361 - 382.

Cox, J. M. and Pearce, M. J. (1983b). Wax produced by dermal pores in three species of mealybug (Homoptera: Pseudococcidae). Int. J. Insect Morphol. Emberyl., 12 (4), 235 - 248.

Ezzat, Y. M. (1962). A synopsis of the family Pseudococcidae as known in Egypt, U.A.R. (Homoptera: Coccoidea). Bull. Soc. ent. Egypt $46,155-170$.

Ferris, G. F. (1950). Atlas of scale insects of North America .ser. V, The Pseudococcidae (Part 1). Stanford Univ. Press. 278pp.

Foldi, I. and Pearce, M. J. (1985). Fine structure of wax glands, wax morphology and function in the female scale insect, Pulvinaria regalis Canard (Hemiptera: Coccidae). Int. J. Insect Morphol. Emberyol. 14, 259 - 271.

Gullan, I. J. and Kosztarab, M. (1997). Adaptions in scale insects. Ann. Rev. Entomol. 42, 23 - 50.

Kaydan, M. B. and Gullan P. J. (2012). A taxonomic revision of the mealybug genus Ferrisia Fullaway (Hemiptera: Pseudococcidae), with descriptions of eight new species and a new genus. Zootaxa 3543, 65 pp.

Khalifa, , Elham; El-Sebaey, A.; Iman, A. I.; Zein, H.S. and El-deab, Marwa M. (2019). Taxonomic studies of common genera and species of family Pseudococcidae (Hemiptera:Coccoidea) with taxonomic key in Egypt. Egypt J. Plant Prot. Inst. 2(1), 49 - 66.

Kumar, V.; Tewari, S. K. and Datta, R. K. (1997). Dermal pores and wax secretion in mealybygs Maconellicoccus hirsutus (Hemiptera: Pseudococcidae). A pest of mulberry. Ital. J. Zool. 64(04). 307 - 311.

Le Ru, B.; Renard, S.; Allo, M.; Lenlannic, J. and Rolland J. P. (1995). Ultrastructure of sensory receptors on the labium of the cassava mealybug Phenacoccus manihoti MatileFerrero Entomologia Experimentalis et Applicata 77, $31-36$.

Mc Kenzie, H. L. (1967). Mealybugs of California, with taxonomy, biology and control of North American species (Homoptera: Coccoidea: pseudococcidae). VIII +526 pp. 25 coll. Pls. 205 Fig. 193 maps. Perkeley\& Los Angeles California.

Mohamed, A. H. (2015).Taxonomy, biology and ecology of the newly spreading mealybug .Annual Report 2014/2015. IPM Research and Training Centre, Crop Protection Research Centre, Agricultural Research Corporation.

Schmutterer, H. (1969). Pests of crops in Northeast and Central Africa, with particular reference to the Sudan. Gostav Fischer Velog , Stuttgart, 296 pp.

Sirisena, U. G. A. I.; Watson, G.W.; Hemachandra K. S. and Wijayagunasekara H. N. P. (2015). Scanning electron microscopy of sx selected mealybug (Hemiptera: Pseudococcidae) species of Sri Lanka. Tropical Agricultural Research Vol. 26 (2), 237 - 247

Tewari, S. K.; Kumar, V. and Datta, R. K. (1994). Scanning electron microscope observations on the mealybug Maconellicoccus hirsutus (Green), a major pest of mulberry (Homoptera: Pseudococcidae).Giornale Italiano de Entomologia 7(38), 157 - 164.

Ubero-Pascal, N.; Arnaldos, I; Lopez-Esclapez, R. and Garcia, M. D. (2010). Microscopy and forensic entomology. Pp.1548 - 1556. In Mendez-Vilas, A. and Diaz, J. (Ed.) Microscopy science, technology, application and education, Microscopy book series No. 4. Formatex Research Center, Badajoz, Spain.

Vahedi, H. A. and Mahfar, F. G. (2010). Scanning electron microscope observation on the multilocular disc pores and the dermal projections of adult female Porphyrophora tritici and P. cynodontis. Entomol. Hellenica, $19,76-81$.

Williams, D. J. and Granara deWillink, M. (1992). Mealybugs of central and south America 1ed. CAB International. Wallingford. 635pp.

Zhang, Y. ; Xie, Y.; Xue, J.; Fu, X. and Liu, W. (2012). The Structure of integument and wax glands of Phenacoccus fraxinus (Hemiptera: Coccoidea: Pseudococcidae). Zool. Res. 33 E13-E1.doi:10.324/SP.J.1141.2012.E01-02E13. 


\title{
Ferrisia malvastra (McDanial) دراسة بالميكروسكوب الماست للبق الدقيقى
}

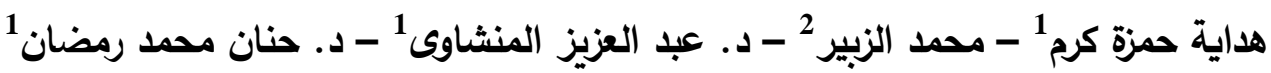 \\ ' قسم الحشرات و الحيوان التطبيقى، كلية الززاعة جامعة الاسكندرية

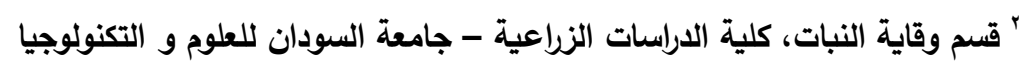

أجريت هذه الدراسة على البق الدقيقى Ferrisia malvastra (McDanial) الذى يعتبر تسجيلا جديدا فى السودان

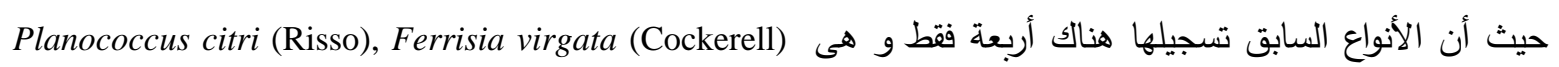
and Phenacoccus hirsutus Green and Phenacoccus solenopsis Tinsley تم فى هذه لدراسة فحص و تصوير التركيب الدقيق لبعض الصفات المورفولوجية باستعمال الميكروسكوب الإكترونى

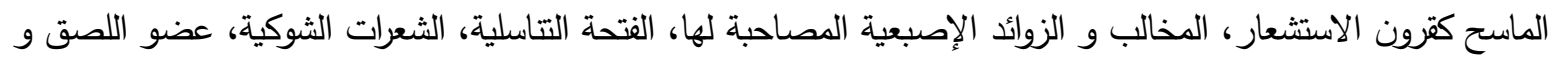

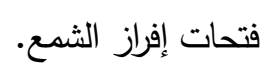
أظهرت النتائج أن قرون الأستثعار تتكون من ثمانى حلقات و تم قياس اطوالها و وصف أعضاء الحس عليها. و

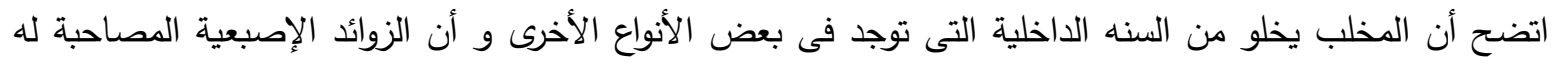

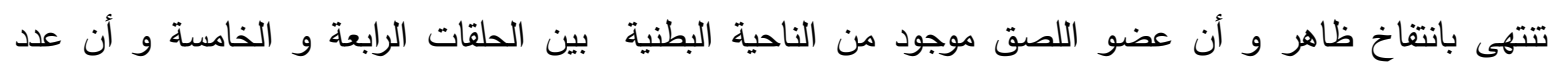

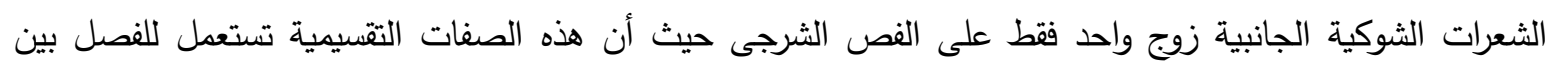

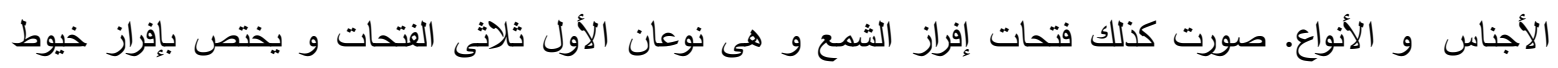

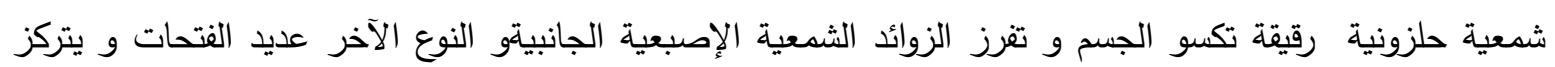
حول الفتحة التتاسلية الأنثوية و يفرز خيوط شمعية شريطية الثكل يحيط بالبيض و يكون كيس البيض. 